\title{
Adaptive characteristics of main muscular groups' static endurance in 6 years children in initial school period
}

\author{
Bondarenko S.V. \\ Kirovohrad State Pedagogical University, Kirovohrad, Ukraine
}

\begin{abstract}
Purpose:

to study adaptation of 6 years children's muscular skeletal apparatus to learning work by indicators of static endurance dynamic.

Material: $\quad$ in the research 6 years children participated $(n=64$, boys $-n=36$, girls $-n=28$ ). Indicators of main muscular groups' static endurance were studied.

Results: $\quad$ we determined comparative topography of 13 muscular groups' static endurance and substantial sex dimorphism was found. In 9 muscular groups the boys advantage was $11.7-50.2 \%(p<0.05 \div 0.01)$. The level and correlation of muscles-antagonists' static endurance from the point of evolutionary and ontogeny development of muscular-skeletal apparatus were substantiated. At the end of semester we found significant $(p<0.001)$ reduction of static endurance indicators as well as the fact that torso muscles were the most sensitive to influence of learning work's static component. The level of static endurance weakening, under which syndrome of static over-tension appears, was determined.

Conclusions: the research results permit to balance the volumes of learning load at initial stage of school work. Organizational-methodic principles of learning and physical education system for children shall be oriented on overcoming muscular-skeletal apparatus's dysfunctions.

Keywords: children, school loads, static endurance, posture, endurance, static.
\end{abstract}

\section{Introduction}

Adaptation of children's organism to school loads attracts more and more attention. It is connected with great influence of learning loads on schoolchildren's health. Dynamic of schoolchildren's health worsening with every school year is commonly known.

It is proved by numerous data about causal relationship between the temps of learning process's intensification and dynamic of pupils' health worsening $[1,2,22,30]$.

But medical specialists think that for complete and objective characteristic of children's health it is necessary to study age specificities and laws of physical, mental and functional state in different periods of ontogeny. For this purpose it is necessary to regard all processes of growth, in particular through physical and nervouspsychic adaptation to environmental factors. That is why "children's health" is studied in respect to biological age: life activity, harmonious balance of physical and intellectual characteristics, conditioned by genetic factors and environmental impacts $[12,20]$.

It was determined that in 6 yrs children's adaptation to school load, the type of life activity completely changes. Correlation between motor system's dynamic and static components changes in favor of static component, comparing with pre-school period. This component is conditioned by need in long term sustaining of body static position during lesson. Actually static component is the main learning background, against which the main learning skills of a pupil are formed: reading, writing and counting. In this connection specialists-physiologists stress on the fact that for children, from all three kinds of school loads (mental, dynamic and static) the most tiresome is static [9, 31, 39].

Static component of school loads has great deformation (c) Bondarenko S.V., 2017

doi:10.15561/18189172.2017.0402 potential, which negatively influences on morphological functional state of backbone. Deviations in muscularskeletal apparatus and posture are the most wide-spread nosologies of primary schoolchildren [8, 18, 32, 35]. It was found that weakening of primary schoolchildren's static endurance negatively impacts on such goniometric indicators of backbone as: cervical lordosis, thoracic kyphosis in sagittal plane, backbone scoliosis in frontal plane $[2,24,26]$.

That is why it is important to study adaptation reactions of muscular skeletal apparatus through dynamic of static endurance indicators of different muscular groups. Study of children's adaptation to learning loads can have great diagnostic importance. It can help to prevent from posture disorders even at pre-nosological and pre-morbid levels.

It explains specialists' attention to indicators of torso muscles static endurance in schoolchildren of all age groups [19, 27, 29, 38,]. Especially it concerns primary schoolchildren $[22,35,37]$. Some works are devoted to topography of static endurance of different muscular groups [5, 31, 28]. In analytical researches authors note difficulties, which appear as result of instrumental methodic application (dynamometers with "falling hands") and inaccuracy in static endurance measuring with the help of field tests: Sorensen's test and its modifications (test of Biring-Sorensen, BCME) for primary school age children [33].

But we have not found any works, devoted to static endurance adaptation in initial school period in available data base.

The hypothesis of the research stipulated that static component of school loads shall reflect in indicators of static endurance of children's main muscular groups in the process of adaptation to school loads.

The purpose of the work is to study adaptation of 6 
years children's muscular skeletal apparatus to learning work by indicators of static endurance dynamic during first semester.

\section{Material and methods}

Participants: in the research 6 years children participated $(\mathrm{n}=64$, boys $-\mathrm{n}=36$, girls- $\mathrm{n}=28$ ), school № 18,31 (Kropivnitskiy), who, by results of the last medical examination, were related to main and preparatory health groups. The parents gave consent for their children's participation in experiment.

Organization of the research: the methodic of static endurance study shall consider the following age characteristics of children: inability to keep static muscular effort at one level; absence of exact differentiated static effort; spontaneous changing of physical workability phases $[5,9]$. The methodic of dynamography by Ianchevskij A.A. meet such requirements [6]. It permits to measure static endurance (in contrast to other methodic, which only register the duration of effort) by the functions of two variables of static effort: force and time. It permits to calculate the results in units of impulse $(\mathrm{kg} / \mathrm{sec})$. When recording on electrotensodynamograph the value of area under the curve of effort's reduction will be an integral indicator of static endurance. Romanenko V.A. also notes the purposefulness and advantages of such methodic [13].

In our research we used electrotensodynamograph ETD - 1 [11]. Recording of static efforts took place at speed of tape movement $90 \mathrm{~mm}$ per minute on coordinate paper. Preciseness of force function's recording was \pm 100 $\mathrm{g}$, and time function- $0.1 \mathrm{sec}$. Measurements of strength and static endurance of hand's, torso and foot muscular groups were realized in positions, recommended by Korobkov A.V. [10]. Muscular groups of upper and lower limbs were measured as per recommendations of Rybalko BM. [15]. For this purpose we made dynamometric platform.

The scheme of the research included registration of strength and static endurance indicators at the beginning and at the end of first academic semester. It corresponds to the ideas about formation of formation of urgent, not stable and long-term adaptation of pupils' organisms to school loads $[1,2,9]$.

Statistical analysis: the received results were processed with the help of mathematical statistic methods. We calculated the following values: mean arithmetic $(\mathrm{M})$, mean square deviation $(\delta)$; average error of mean arithmetic (m). Confidence of differences was found with the help of Student's t-test at admissible $5 \%$ level of significance $(\mathrm{p}<0.05)$.

\section{Results}

Initial registration of indicators, conducted at the beginning of semester gave the following results:

The received data show that in 6 yrs children sex dimorphism are rather clear in static endurance indicators. Boys' advantage was registered in 8 muscular groups and was $12-26 \%$. In six muscular groups advantage was statistically confident.

By static endurance indicators extensors dominate over flexors, excluding arm flexors. It coincides with the data of other authors $[5,35]$. Foot flexors are not

Table 1. Indicators of 6 yrs children's static endurance at the beginning of semester (September) $\mathrm{M} \pm \mathrm{m}$

\begin{tabular}{lll}
\hline Muscular groups & \multicolumn{2}{c}{ Indicators of static endurance $(\mathbf{k g} / \mathbf{s e c})$} \\
& Boys $(\mathbf{n}=\mathbf{3 6})$ & Girls $\mathbf{( n = 2 8 )}$ \\
\hline Upper limbs & & $122,4 \pm 5,09$ \\
Forearm flexors & $135 \pm 5,31$ & $165,2 \pm 7,60$ \\
Forearm extensors & $174,2 \pm 6,46$ & $176,6 \pm 4,86$ \\
Arm flexors & $168,5 \pm 6,95$ & $73,2 \pm 2,98$ \\
Arm extensors & $119,9 \pm 4,86$ & \\
Lower limbs & & $188 \pm 10,33$ \\
Foot flexors & $240,9 \pm 15,35$ & $81,4 \pm 6,58$ \\
Foot extensors & $122,4 \pm 3,37$ & $52,7 \pm 3,37$ \\
Shin flexors & $8,97 \pm 3,01$ & $131,3 \pm 5,96$ \\
Shin extensors & $173,8 \pm 8,82$ & $64,1 \pm 3,46$ \\
Thigh flexors & $81,7 \pm 3,83$ & $244,1 \pm 9,08$ \\
Thigh extensors & $297,9 \pm 14,74$ & \\
\hline
\end{tabular}

Table 2. Static endurance indicators of the most sensitive for learning work's static component muscular groups of 6 yrs children (September) $\mathrm{M} \pm \mathrm{m}$

\begin{tabular}{lcc}
\hline \multirow{2}{*}{ Muscular groups } & \multicolumn{2}{c}{ Indicators of static endurance $(\mathrm{kg} / \mathbf{s e c})$} \\
& Boys $(\mathbf{n = 3 6 )}$ & Girls $(\mathbf{n = 2 8 )}$ \\
\hline Hand's flexors & $234,3 \pm 5,26$ & $156 \pm 9,42$ \\
Torso flexors & $414,4 \pm 16,28$ & $371,1 \pm 13,98$ \\
Torso extensors & $568,4 \pm 17,90$ & $549,8 \pm 17,84$ \\
\hline
\end{tabular}


considered because of their anatomic specificity.

It was also found that rank levels of static endurance indicators do not coincide with biomechanical indicators of muscular groups' mass. Especially it is noticeable in case of lower limbs, where static endurance maximal indicators were registered in the most massive thigh extensors and in the least massive (foot flexors). Such peculiarities shall be connected with evolution process of formation of human orthography body position: with functions of straight carriage, based on tension of the mentioned muscular groups [8].

Functionally it is ensured by mechanisms of long term adaptation reactions to influence of specific for cells and their structural elements physical loads [4].

It is important to study children organism's adaptation to static component of school loads, especially muscular groups of torso and hand. It is connected with ergonomic specificities of pupils' learning work, which requires forced motor functioning. This functioning is regulated by algorithm of educational process. This algorithm envisages working sitting position with restricted movements of hands and torso [7].

By the data of table 2 boys' advantage in the mentioned muscular groups was also expressive. In hand's flexors by $50.2 \%(\mathrm{t}=7.26 ; \mathrm{p}<0.001)$, in torso flexors - by $11.67 \%$ $(\mathrm{t}=2.03 ; \mathrm{p}<0.05)$, in torso extensors - by $31.8 \%(\mathrm{t}=$ $0.74 ; \mathrm{p}>0.05)$. It was found that torso muscular groups have the highest indicators of static endurance among all thirteen segments of body. Torso extensors have confident advantage in boys by $37.2 \%(\mathrm{t}=6.37 ; \mathrm{p}<0.001)$ and in girls - by $48.2 \%(\mathrm{t}=7.9 ; \mathrm{p}<0.001)$.
The next registration of static endurance indicators was fulfilled in December. It permitted to determine of 6 yrs. children's adaptability to school loads and influence of their static component.

The data of table 3 show adaptation process of $6 \mathrm{yrs}$ children's muscular skeletal apparatus to static component of learning work. Static endurance indicators of upper limbs have tendency to reduction in all four muscular groups. In boys it was registered in the range 5.4-24.5\%; in girls $-2.7-22.3 \%$. In boys static endurance reduction of forearm extensors and arm flexors are confident, accordingly $24.5 \%(\mathrm{t}=4.38 ; \mathrm{p}<0.01)$ and $13.2 \%(\mathrm{t}=$ $2.26 ; \mathrm{p}<0.05)$. In girls such noticeable reduction was found in forearm extensors $-22.3 \%(t=3.1 ; \mathrm{p}<0.01)$ and arm flexors $10 \%(\mathrm{t}=2.52 ; \mathrm{p}<0.05)$.

In indicators of lower limbs' static endurance we also registered general tendency to reduction of results. In boys it reached $5-28.7 \%$. In boys the highest reduction of static endurance was in group of thigh extensors$28.7 \%(t=2.19 ; \mathrm{p}<0.05)$. In girls the range of reduction was $12.1-17.4 \%$, while in group of thigh extensors the values become confident $(\mathrm{t}=2.28 ; \mathrm{p}<0.05)$.

It should be noted that static endurance of lower and upper limbs noticeably inhibits under influence of new learning conditions of children's life activity. Muscles of torso prove it even more expressively.

By the data of table 4 we see negative type of dynamic of torso static endurance indicators at the end of semester. In boys, in torso flexors' group this reduction was $22.4 \% \mathrm{t}$ $=12.4 ; \mathrm{p}<0.001)$, and in torso extensors' group $-13.1 \%$ $(\mathrm{t}=3.61 ; \mathrm{p}<0.001)$.

Table 3. Static endurance indicators of 6 yrs children at the end of first academic semester (December) $M \pm m$

\begin{tabular}{lll}
\hline Muscular groups & \multicolumn{2}{l}{ Indicators of static endurance $(\mathbf{k g} / \mathbf{s e c})$} \\
Boys $(\mathbf{n}=\mathbf{3 6})$ & Girls $(\mathbf{n = 2 8})$ \\
\hline Upper limbs & $127,7 \pm 8,18$ & $119,1 \pm 7,68$ \\
Forearm flexors & $131 \pm 7,28$ & $128,4 \pm 9,16$ \\
Forearm extensors & $146,2 \pm 7,0$ & $159 \pm 5,02$ \\
Arm flexors & $104,2 \pm 5,12$ & $70,4 \pm 6,14$ \\
Arm extensors & & \\
Lower limbs & $201 \pm 16,11$ & $167,4 \pm 12,44$ \\
Foot flexors & $116,3 \pm 8,16$ & $70,5 \pm 10,17$ \\
Foot extensors & $38,6 \pm 4,15$ & $46,3 \pm 5,48$ \\
Shin flexors & $164,7 \pm 9,16$ & $119,2 \pm 10,21$ \\
Shin extensors & $64,9 \pm 3,26$ & $59,9 \pm 4,08$ \\
Thigh flexors & $212,4 \pm 36,11$ & $201,6 \pm 73,18$ \\
Thigh extensors & & \\
\hline
\end{tabular}

Table 4. Static endurance indicators of the most sensitive for learning work's static component muscular groups of 6 yrs children (December) $\mathrm{M} \pm \mathrm{m}$

\begin{tabular}{lll}
\hline \multirow{2}{*}{ Muscular groups } & \multicolumn{2}{c}{ Indicators of static endurance $(\mathbf{k g} / \mathbf{s e c})$} \\
& Boys $(\mathbf{n}=\mathbf{3 6})$ & Girls $(\mathbf{n = 2 8})$ \\
\hline Hand's flexors & $231,7 \pm 13,91$ & $159,5 \pm 12,16$ \\
Torso flexors & $321,4 \pm 17,26$ & $177,2 \pm 17,06$ \\
Torso extensors & $494 \pm 10,28$ & $465 \pm 18,08$ \\
\hline
\end{tabular}


In girls static endurance indicators of torso flexors reduced by $52.3 \%(\mathrm{t}=8.81 ; \mathrm{p}<0.001)$ and extensors by, $15.4 \%(\mathrm{t}=3.34 ; \mathrm{p}<0.001)$.

In our opinion just this, critical reduction of static endurance explains higher quantity of deviations and posture disorders in primary school age girls[3, 8, 12]. Our assumption about reduction of hand's flexors turned out to be mistaken, as far as we registered only slowing of dynamic of indicator within $1-2 \%$.

\section{Discussion}

The received by methodic of Ianchevskij A.A. [6] data permitted to collect rather complete information about comparative topography of static endurance indicators in main muscular groups of children at the beginning of school learning.

In the area of upper limbs the highest indicators were registered in forearm's extensors and the lowest - in arm's extensors. In girls such changes were found in flexors and extensors of arm. In muscular group of forearm the situation was quite opposite - extensors' indicators prevailed. In the area of lower limbs static endurance indicators were higher in the group of thigh and shin extensors.

Such functional variety in static endurance indicators in all groups of flexors-extensors is explained by the fact that all muscular groups participate differently in children's motor functioning. That is why they change differently by absolute indicators of static endurance and by temps of their increment with age [5].

In our opinion specificity of static endurance topography in different body segments is explained by two main factors: biomechanical mass of muscular group and their evolution adaptation to static regimes of work. The received data of indicators of torso muscular groups, which have the highest mass and static endurance, prove our affirmations. One more argument is phenomenon of foot flexors (which have the least mass) and whose static endurance is dominating in limbs' segments. It is considered that it is connected with ontogeny formation of muscular skeletal apparatus: function of upright moving and interaction with gravitation factors in the process of posture formation. Formation of posture can be regarded exactly as a product of evolution morphological perfection of muscular skeletal apparatus under influence of human gravitation interaction with surrounding world $[5,8]$.

Thus, correlation of lower limbs' and torso's static edurance indicators should be explained by their functional significance in ensuring upright walking: achievement and sustaining of optimal regional postural muscular balance (tonus-power balance of musclesantagonists, which ensures physiological uniformity of load on backbone) [17].

It was also found that in indicators of boys' and girls' static endurance sex dimorphism is rather clear in all studied muscular groups. The boys' advantage was statistically confident in the range $(p<0.05 \div 0.001)$. The data of different researchers in this question are rather contradictory that is explained by application of different methodic. Rather often such methodic did not meet age characteristics of primary school age children. In other work it is stated that eight age children were not able to sustain constant effort of 50\% from maximal strength. It forced to repeat attempts [5].

Unanimity of scientists' positions in respect of static endurance of different age people means recognition of the fact that indicators of development in ontogeny has progressive and non uniform character. Primary school age has insignificant increments of strength indicators. That is why this age is characterized by noticeable increase of static endurance $[5,35]$.

The received data deepen and supplement information about children organism's adaptation to static component of school loads: change of motor regime of life activity in general. It was found that inhibited and negative type of static endurance dynamic is present, in different degree, in all thirteen studied muscular groups. It was found that the most sensitive to static component's influence were torso extensors and flexors. We think that it is connected with absence of formed, stable correct working position at school desk. Besides, it is connected with the fact that children cannot control position of torso and head, when mastering reading, writing and other required skills [36].

Reduction of torso flexors' static endurance indicators was much higher than extensors' both in boys and girls. It results in statement that there is syndrome of static over-loading (the term, proposed by us) of primary school children's organism. This term appeared after four months' school learning, providing all requirements to organization of educational process in primary school were observed.

From position of ecological physiology (the branch of labor physiology) [16] syndrome of static overloading shall be regarded as localization of general overloading syndrome in nervous-muscular apparatus of 6 yrs children. It is formed as a result of log term static fatigue, not completely compensated in restoration period [14]. It results in chronic disorders. The work, fulfilled under impact of stimulus is characteristic feature of chronic disorders. Ul'mer G. Notes that syndrome of overloading is especially noticeable in organs, sustaining body position [16]. In our case deforming influence of long term sitting on children organism's postural and motor systems causes emersion of constant disorders of backbone. It is noticeable after leaving primary school [1, 2, 8, 12].

In the works by Bazarnyj V.F. [1] reflex of bent head was found in most of primary school pupils. This reflex also appeared at the end of December. It witnesses about formation (to be more exact about functional disorder of cervical and thoracic backbone segments) of kyphosis carriage - slouch. It I a result of static over-loading syndrome's progressing.

It is quite clear that the conducted research covers chronologically only the stages of urgent and non stable adaptation of children to static component of school loads. It is only a part of all adaptation process. It makes narrower the opportunity of conclusions about generalized characteristics of adaptation process's formation in $6 \mathrm{yrs}$ 
children.

The prospects of further researches imply studying of laws of primary school age children's long term adaptation mechanisms to school loads. The received data contradict to researches, which indirectly support further intensification of education process and do not consider biological potentials of pupils [9, 37].

The novelty in our work is: we are the first who received detail and complete topography of static endurance of al thirteen 6 yrs boys' and girls' muscular groups. We found significant and statistically confident sex dimorphism between static endurance indicators of boys and girls in all muscular groups. We also made an attempt to substantiate the level of static endurance first of all in: foot flexors; thigh extensors; torso flexors and extensors. This attempt was regarded from positions of evolution and ontogeny formation of muscular-skeletal apparatus, connected with functions of upright posture and walking under influence of gravitation factor.

Analysis of static endurance indicators' dynamic permitted to differentiate, for the first time, syndrome of static overloading. It can be regarded as pre-morbid state in respect to possible deformation of sitting posture at school desk and in general the posture of primary school age children. We deepened the ideas about duration and special aspects of $6 \mathrm{yrs}$ children's adaptation to static component of school loads.

\section{Conclusions}

Study of 6 yrs children's adaptation to static component of school loads by static endurance indicators permits to substantiate the need in reducing the volumes of school loads at initial stage of school period.

Static endurance of lower limbs and torso muscles is an important factor in achievement of optimal postural muscular balance between muscles-antagonists. It is important in formation of correct sitting posture at school desk and carriage in 6 yrs children. Dynamic of static endurance indicators of torso muscular groups is a sensitive integral indicator of organism's fatigue under influence of school loads' static component.

Reduction of static endurance indicators of torso flexors and extensors at the end of first academic semester illustrates emersion and formation of static over-loading syndrome.

Organizational principles of primary school pupils' teaching and the system of physical education shall be oriented on overcoming of failure in 6 yrs children's motor stereotype, which appears in the process of adaptation to school loads' static component.

\section{Acknowledgements}

The research has been fulfilled in compliance with plan of scientific work of Theory and methodic of Olympic and professional sports department of physical education faculty "Formation of pupils' adaptation to school loads by physical education means" (state registration number 0116U005281).

\section{Conflict of interests}

The author declares that there is no conflict of interests.

\section{References}

1. Bazarnyj VF. Children's eyesight. The problems of development. Novosibirsk: Science; 1991. (in Russian)

2. Bondarenko SV. Special aspects of static endurance development and formation of 6-7 yrs children's posture in period of adaptation to school loads. Fizichne vikhovannia, sport i kul'tura zdorov'ia u suchasnomu suspil'stvi, 2015;3(31):117-120. (in Ukrainian)

3. Bondarenko SV. The problem of formation of 6-7 yrs children's adaptation to school loads by means of visual exercises. Naukovo-pedagogichni problemi fizichnoi kul'turi, 2015; (57)15:45-48. (in Russian)

4. Enoka RM. The principles of kinesiology. Kiev: Olympic Literature; 1998. (in Russian)

5. Gorodnichenko EA. Age changes of strength and static endurance of 8-17 yrs pupils' different muscular groups. In: Kuznecova ZI (ed.) Training of schoolchildren's motor qualities. 1967. P. 46-80. (in Russian)

6. Ianchevskij AA. New methodic of sportsmen's motor apparatus's study. Teoriia i praktika fizicheskoj kul'tury, 1960;8:593-596. (in Russian)

7. Karapuzova ND, Zimnicia IeA, Pomogajbo VM. The principles of pedagogic ergonomic. Kiev: Academy; 2012. (in Ukrainian)

8. Kashuba VA. Bio-mechanic of posture. Kiev: Olympic Literature; 2003. (in Russian)

9. Khripkova AG, Antropova MV. Adaptation of students' organism to academic and physical loads. Moscow: Pedagogy; 1982 (in Russian)
10.Korobkov AV, Cherniaev GI, Tret'iakov ND. Methodic of assessment of sportsmen's physical fitness. Physical Culture and Sport; 1963. (in Russian)

11.Lajuni Rida ben Shedli. Modern methods of control over sportsmen's power qualities in training process. Fizicheskoe vospitanie studentov tvorcheskikh special'nostej, 2002;2:2227. (in Russian)

12.Nian'kovs'kij SL, Iacula MS. First form primary schoolchildren's health and their readiness for systemic studying at school. Zdorov'e rebenka, 2010;3(24):10-15. (in Ukrainian)

13.Romanenko VA. Diagnostic of motor abilities. Donetsk: DonNu; 2005. (in Russian)

14.Rovnij AS, Lizogub VS. Psycho-sensor mechanisms of sportsmen's movements' control. Kharkiv: KNCWU; 2016. (in Ukrainian)

15.Rybalko BM. Portable installation for measurements of different muscular groups' strength. Teoriia i praktika fizicheskoj kul'tury, 1966;2:24-27. (in Russian)

16.Ul'mer G, Briuk K, Val'dek F, Gart O, Tevs G. Human physiology. Moscow: World; 1986. (in Russian)

17.Vasil'ev LF. Manual diagnostic and therapy. SanktPeterburg: Foliant; 2001. (in Russian)

18.Allen BA, Hannon JC, Burns RD, William SM. Effect of a core conditioning intervention on tests of trunk muscular endurance in school-aged children. Journal of strength and conditioning research, 2014; 28 (7): 2063-40.

19.Backman E, Odenrick P, Henriksson KG, Ledin T. Isometric muscle force and anthropometric values in normal children 
aged between 3,5 and 15 years. Scandinavian journal of rehabilitation medicine. 1989; 21 (2): 105-114.

20.Bodnar IR, Kindzer AB. Leisure of Ukrainian schoolchildren and place of motor functioning in it. Pedagogics, psychology, medical-biological problems of physical training and sports, 2016; 20(5): 11-18. doi:10.15561/18189172.2016.0502

21.Bondarenko S. 5-6 years old children visual efficiency development in the Period of school loading adaptation by means of visual exercises. The journal of Education. Photon, 2014;106:149-156.

22.Borbelyova D. Adaptation to the school environment in early elementary education. Paidagogos, 2017;2:206-228.

23. Brooke AH. Core muscle endurance and its relation - shipto functional balance and motor play skills in kindergartners. Graduate Program in Allied Medical Professions. The Ohio State University; 2012.

24.Brzek A, Dworrak T, Strauss M, Sanchis-Gomar F, Sabbah I, Dworrak B, et al. The weight of pupils' schoolbags in early school age and its influence on body posture. Bmc Musculoskeletal Disorders. 2017;18.

25.Condon C, Cremin K. Static Balance Norms in Children: Balance, Temporal, Stance, Tandem, Single Leg. Physiotherapy Research International. 2014 Mar;19(1):1-7.

26.Dejanovic A, Balkovec C, McGill S. Head Posture Influences Low Back Muscle Endurance Tests in 11-Year-Old Children. Journal of Motor Behavior. 2015;47(3):226-31.

27. Gras LL, Stockman I, Brolin K. Evaluation of 6 and 10 YearOld Child Human Body Models in Emergency Events. Plos One. 2017;12(1).

28.Habib J, Yurchenko AA, Sergienko KN. Comparative analysis of foot support-spring indicators of primary school age children with weak eyesight in physical education process. Pedagogics, psychology, medical-biological problems of physical training and sports, 2016; 20(2): 59-65. doi:10.15561/18189172.2016.0209

29.Hawke F, Rome K, Evans AM. The relationship between foot posture, body mass, age and ankle, lower-limb and whole-body flexibility in healthy children aged 7 to 15 years. Journal of Foot and Ankle Research. 2016;9.
30.Ivashchenko OV. Classification of 11-13 yrs girls' motor fitness, considering level of physical exercises' mastering. Pedagogics, psychology, medical-biological problems of physical training and sports, 2017; 21(2): 65-70. doi:10.15561/18189172.2017.0203

31.Johnson OE, Mbada CE, Akosile CO, Agbeja OA. Isometric endurance of the back extensors in school-aged adolescents with and without low back pain. Journal of Back and Musculoskeletal Rehabilitation. 2009 Dec 7;22(4):205-11.

32.Lazarenko MG, Troyanovska M M. Pedagogic control of schoolchildren fitness in skiing training with the help of posturography methods. Pedagogics, psychology, medicalbiological problems of physical training and sports, 2017; 21(1): 36-40. doi:10.15561/18189172.2017.0106

33.Moreau CE, Green BN, Johnson CD, Moreau SR. Isometric Back Extension Endurance Tests: A Review of the Literature. Journal of Manipulative and Physiological Therapeutics. $2001 \mathrm{Feb} ; 24(2): 110-22$.

34.Myronenko SG. Adaptation ways to school loads of primary shool children. Bulletin of problems biology and medicine, 2016;1(126):72-75.

35.O'Connell DG, O'Connell JK, Garrett ML, Adams N, Patterson B, Spencer E. isometric strength and dynamic back extensor endurance are unrelated in children ages 6-10 years: a pilot study. Perceptual and Motor Skills. 2004;99(3f):1290-4.

36.Pausic J, Rausavhevic N. Changes in children's posture from the first to the third grate of elementary school. Kinesiologia Slovenica, 2009;15(3):1-7.

37.Telegina NV, Belicheva TV. The criteria of adaption of primary school pupils to the academic load of the increased intensity. International journal of environmental and science education.2016;11(8):2059-2067.

38.Troussier B, Davoine P, de Gaudemaris R, Fauconnier J, Phelip X. Back pain in school children. A study among 1178 pupils. Scand J Rehabil Med. 1994 Sep;26(3):143-6.

39.Zaineev MM, Martyanov OP, Zefirov TL. Reaction of cardiovascular and respiratory system of the first-year pupils the various types of load duriny the school year. Research journal of medicial sciences. 2015;10(3):76-79.

\section{Information about the author:}

Bondarenko S.V.; http://orcid.org/0000-0003-0177-8175; sergeybondarenko1955@mail.ru; Kirovohrad State Pedagogical University; ul. Shevchenko, 1, g. Kropivnitsky, 25006, Ukraine.

Cite this article as: Bondarenko SV. Adaptive characteristics of main muscular groups' static endurance in 6 years children in initial school period. Pedagogics, psychology, medical-biological problems of physical training and sports, 2017;21(4):157-162. doi:10.15561/18189172.2017.0402

The electronic version of this article is the complete one and can be found online at: http://www.sportpedagogy.org.ua/index.php/PPS/issue/archive

This is an Open Access article distributed under the terms of the Creative Commons Attribution License, which permits unrestricted use, distribution, and reproduction in any medium, provided the original work is properly cited (http://creativecommons.org/licenses/by/4.0/deed.en).

Received: 16.03.2017

Accepted: 25.03.2017; Published: 30.08 .2017 